\title{
Have the Purchases of ETF Raised Stock Prices? Recent Japanese Case
}

\author{
Yutaka Kurihara $^{1}$, Shinichiro Maeda ${ }^{2}$ and Akio Fukushima ${ }^{3}$
}

\begin{abstract}
The Japanese central bank, the Bank of Japan (BOJ) has introduced a drastic and unprecedented quantitative easing (QE) policy to combat deflation from the 2000s. The BOJ has purchased exchange-traded funds (ETF) as well as huge amounts of domestic governments bonds. This paper investigates the effect of ETF purchases by the BOJ on Japanese stock prices. Empirical results show that the purchases were conducted to prevent decreasing stock prices, however, whether the purchases directly promoted stock prices rising or not is uncertain in the short-run. On the other hand, as stock prices have been increasing since then, the purchases made situations such as preventing a decrease to stock prices and promoting prices in the long-run.
\end{abstract}

JEL classification numbers: E44, E61

Keywords: Bank of Japan, ETF, stock price

\section{Introduction}

Japan has been under a severe economic condition since the early 1990s. For almost thirty years, deflation has been ongoing and hitting the economy. Some people call these thirty years the 'lost thirty years.' Overcoming deflation has been the main policy objective in Japan. The BOJ and Japanese government have jointly tackled this problem and sometimes drastic and unprecedented measures have been conducted to combat deflation and to boost the economy. One of the most characteristic measures was that the Japanese central bank, the BOJ has introduced a quantitative easing (QE) policy to combat deflation from the 2000s. Since the 2010s, the BOJ has promoted such policies and purchased ETF, as domestic governments have also done.

This paper investigates the effect of ETF purchases by the BOJ on Japanese stock prices. Examining this policy is important because there are many criticisms for this policy. One is whether this policy is effective or not, of course, on the other hand, there are some criticisms for purchasing large amounts of stocks by the central bank. In reality, central banks purchase stocks which are regarded as risky compared to other assets such as domestic government bonds. This has also been unprecedented. However, there is little study to analyze these problems in spite of their importance. Recently, Hattori (2020) showed that the impacts of the demand factor on the term structure significantly affects the Japanese government bond price, but there is little study for ETF purchases not only for Japanese cases but also towards other

\footnotetext{
${ }^{1}$ Faculty of Economics, Aichi University, Japan

${ }^{2}$ Faculty of Economics, Kyushu University, Japan

${ }^{3}$ Faculty of Institute for Economic Studies, Seijo University, Japan
} 
countries' cases.

This paper is structured as follows. Section 2 reviews recent Japanese experiences from the Lehman shock to now. In addition, a history of monetary policy conducted in each period is reviewed and existing studies are checked. Section 3 performs preliminary confirmations for empirical analyses. Based on these confirmations, empirical analyses are performed and the results are analyzed in section 4. Finally, summaries and brief a conclusion are provided in section 5 .

\section{Japanese experiences}

The Japanese economy enjoyed rapid growth from the middle of the 1980s, however, that 'bubble' economy burst in the early 1990s. After that deflation occurred, the situation has continued through the present. In 2008, Lehman shock occurred worldwide. When the Lehman shock happened in 2008, it led to an inflow of tremendous funds into the Japanese financial markets to avoid global financial risks despite the fact that the Japanese economy was still not strong. At that time, such capital inflow promoted the Japanese yen's appreciation, which hit the Japanese economy because market participants expected a deterioration on exports which hit the Japanese economy.

Just after the recovering of the economy, Japan had been again into recession. Deflation had been ongoing. Lehman shock occurred at that time unfortunately. The BOJ decided to conduct unprecedented QE policy to overcome the deflation in October 2010. The BOJ announced the plan to change the main operating target for its money market operations from the uncollateralized overnight call rate to the monetary base as interest rates were quite low and there was no way to decline interest rates (call rate is an interest rate). It should be noted that one of the important policies at that time was an asset purchase program that included Japanese government bonds and private assets related with stocks including ETF. ETF purchases started from 2010. ETF is a kind of security and is listed on exchanges and traded. ETF in Japan tracks the Nikkei 225 Stock Average, Tokyo Price Index (TOPIX), or the JPX-Nikkei Index 400 (Nikkei is a Japanese newspaper company). The BOJ, as trustor and beneficiary, appoints a trust bank as trustee, and makes a money trust, with which ETFs and J-REITs are purchased as its trust property. Also, a fiscal policy with a large budget along with such drastic monetary policy was of course implemented.

At the end of 2012, a political regime change occurred in Japan. Abenomics, promoting QE and large fiscal expansion (Abe was the prime minister's name) was conducted, and the yen deprecated greatly and stock prices rose greatly. It is interesting to note that although interest rates were almost zero, stock prices had not risen by large amounts before that.

A lot of studies related with these topics have been presented from the 2010s. Fukuda (2011) showed that, under Abenomics, foreign investors tended to buy Japanese stocks and sell the Japanese yen, although domestic investors did not do so very much. Kurihara (2014) found that Abenomics provided some positive influence on stock prices. Lam (2015) indicated that the BOJ could have realized the yen's depreciation and could have maintained a low interest rate condition. Kurihara (2016) showed that a zero interest rate policy in Japan and the yen/dollar exchange rate depreciation had positive impacts on Japanese stock prices. On the other hand, Fujiwara, Nakazono, and Ueda (2015) found that Japan seemed to be under a long-term liquidity trap and there was no clear difference before and after the conduction of Abenomics. Only a short time has passed since the drastic measures were employed, there is no consensus on the evaluation of recent economic policies.

The relationship between ETF and stock prices has not been analyzed for Japanese cases much so far, however, there started to appear a lot of studies for the relationship of foreign cases. Yamori (2011) indicated that commodity ETFs promoted transactions in traditional commodity futures markets. Tse (2012) showed that Granger-causality in returns goes forward to agricultural ETFs using daily data. Liu and Tse (2017) found that there was a positive relationship between US exchange-traded index funds and international index futures. Chang, Hsieh, and McAleer (2018) showed that daily VIX returns have a relationship on each European ETF return negatively. Ben-David,Franzoni, and Moussaw (2018) indicated that ETF ownership increases autocorrelation negatively in stock prices. Lee and Kim (2018) 
found that ETF managers' rebalancing transactions have an impact on the daily returns of the related stocks in Korea. Nie, Jiang, and Yang (2018) showed evidence of linear causality from the US stock market with the Chinese ETF markets. Rompotis (2018) found a co-movement between the US ETF market and the related emerging markets. Wang et al. (2018) showed that cost spread ETF option, option volatility, days from the expiration date, money-ness of ETF options, trading strategy, and policy factors all have impacts on the arbitrage transactions. Matousek et al. (2019) found that Japanese regional banks have positive impacts of QE on economic growth via equity holdings. Narend and Thenmozhi (2019) found that India ETFs have an impact on stock indexes in India by employing a pooled OLS.

ETF prices themselves have been analyzed. Li and Zhao (2014) showed that both quoted and effective spreads of component stocks increase about 0.2-3.0 points after the introduction of leveraged-type ETFs. Papadamou et al. (2017) showed that asset selection has a significant relationship with returns before and after the global crisis occurred in 2008. Romotis (2017) found a relationship between the US and emerging Asian ETF markets significantly. Fassas and Papadamou (2018) showed that equity variance risk premium is one predictor of equity returns. Sanderson and Lumpkin-Sowers (2018) indicated that it takes ten years for the probability of a profit on principle to be over 95 percent. Cheng et al. (2019) found that the real investments of ETF departs from their benchmarks to leverage informational advantages. Kyriazis et al. (2020) indicated that evidence of an improvement in selectivity and market timing skills for Greek equity mutual finds after the debt crisis.

Finally, Charoenwong et al. (2019) showed that the return elasticity of stocks with respect to BOJ purchases for one month previous is about twice and increases in the long-term. However, this paper focuses on much shorter periods using daily data.

\section{Empirical analyses}

The main focuses of this study are to examine the relationship between ETF purchases by the BOJ and stock prices in Japan. The purchases by the BOJ are sometimes criticized as there is some possibility that market distortions could occur. Also, the BOJ should take risks as the balance sheet of the bank expands. Moreover, there could be some possibility that investors in reality are crowded out. There is some possibility that they cannot purchase ETF in some situations. Whether examining this policy is effective or not, should depend on empirical analyses.

The data used are Japanese Nikkei 225 Average (stockprice), ETF purchases by the BOJ (ETF), yen/dollar exchange rate (exchange), 10-year Japanese government bond yield (10bond), Dow Jones (DOW), and S\&P (S\&P). All of the data except ETF are from Nikkei Telecom (a Japanese newspaper company provides this information). The data of ETF are from the BOJ website (the unit is 100 million yen). ETF purchases are not conducted every day, however, the purchases are sometimes conducted continuously for several days.

The closing data of Japanese stock prices of each data are used for estimation as markets sometimes imagine the purchases of ETF by the BOJ without notification by the BOJ. For exchange rates, the averages are employed as they fluctuate over a very short-time.

All of the data except ETF and 10bond have unit roots, so the rates of stockprice, exchange, DOW, and $\mathrm{S} \& \mathrm{P}$ are used in estimation. The Dickey-Fuller test is employed to idicate whether the data (rate) have unit roots or not. Table 1 shows the results of the test. 
Table 1: Augmented Dickey-Fuller test

\begin{tabular}{|c|c|c|}
\hline variable & t-statistic & Prob. \\
\hline stockprice & -43.715 & 0.000 \\
\hline ETF & -14.261 & 0.000 \\
\hline exchange & -45.440 & 0.000 \\
\hline 10bond & -12.385 & 0.000 \\
\hline DOW & -29.206 & 0.000 \\
\hline S\&P & -29.806 & 0.000 \\
\hline
\end{tabular}

In Table 1, all of the data have no unit roots. Following these test results, the rates of each data are used for estimations. Finally, for ETF purchases, dummy variables (1: purchases, 0: no-purchases) are also used for estimations.

\section{Empirical results and analyses}

To examine the effects of ETF purchases on Japanese stock prices, regression analyses are employed. First, the impacts of ETF purchases on stock prices are directly examined. The estimation equation is (1).

stockprice $=\alpha+\beta \operatorname{ETF}(\mathrm{t})$

There is some possibility that the market knows the purchases by the BOJ when some time has passed, so the time lag (day) is taken into accounts. In the equation, $t$ denotes time. The results of the estimations are in Table 2. (-1), (-2), and indicate yesterday, day before yesterday, and so on.

Table 2: The effects of ETF purchases on stock prices

\begin{tabular}{|c|c|c|c|c|c|c|}
\hline $\mathrm{C}$ & $\begin{array}{l}0.003 * * * \\
(11.667))\end{array}$ & $\begin{array}{c}0.0009 * * * \\
(2.718)\end{array}$ & $\begin{array}{c}0.0006^{*} \\
(1.937)\end{array}$ & $\begin{array}{l}0.0005 \\
(1.468)\end{array}$ & $\begin{array}{c}0.0005^{*} \\
(1.646)\end{array}$ & $\begin{array}{l}0.0005 \\
(1.545)\end{array}$ \\
\hline ETF & $\begin{array}{c}-1.93 \mathrm{E}-05^{* * * *} \\
(-19.866)\end{array}$ & & & & & \\
\hline $\operatorname{ETF}(-1)$ & & $\begin{array}{c}-2.11 \mathrm{E}-06^{* * *} \\
(-1.983)\end{array}$ & & & & \\
\hline $\operatorname{ETF}(-2)$ & & & $\begin{array}{c}-4.12 \mathrm{E}-07 \\
(-0.386)\end{array}$ & & & \\
\hline $\operatorname{ETF}(-3)$ & & & & $\begin{array}{l}6.62 \mathrm{E}-07 \\
(0.6213)\end{array}$ & & \\
\hline ETF(-4) & & & & & $\begin{array}{c}2.43 \mathrm{E}-07 \\
(0.227)\end{array}$ & \\
\hline $\operatorname{ETF}(-5)$ & & & & & & $\begin{array}{c}4.41 \mathrm{E}-07 \\
(0.412)\end{array}$ \\
\hline Adj.R2 & 0.172 & 0.001 & -0.0004 & -0.0003 & -0.0005 & -0.0004 \\
\hline F-statistic & 394.682 & 3.934 & 0.148 & 0.386 & 0.051 & 0.170 \\
\hline Prob(F-statistic) & 0.000 & 0.047 & 0.699 & 0.534 & 0.819 & 0.679 \\
\hline $\begin{array}{l}\text { Akaike info } \\
\text { criterion }\end{array}$ & -6.007 & -5.818 & -5.816 & -5.816 & -5.816 & -5.815 \\
\hline D.W. & 2.051 & 2.053 & 2.015 & 2.014 & 2.015 & 2.015 \\
\hline
\end{tabular}

Notes) Parentheses are t-value. $* * *, * *$, and $*$ are significant at 1,5 , and $10 \%$ levels. 
The results are clear. The coefficients of the purchasing day and one-day before are significant. However, the coefficients are negative not positive. In the case of using the first differences of ETF purchases and stock returns and in the case of using squared terms, the results do not change. According to the results, the purchase of ETF seems to be conducted to prevent declining stock prices, however, sometimes the purchases were conducted against the strong flow of stock prices. The purchases were not effective at first. However, stock prices rise later. Also, two, three, four, and five days later, the coefficients change from negative to positive (however, they are not significant). So, there is some possibility that market distortion via massive purchases of ETF seems to be avoided.

Table 3 presents the results of equation (1) using data of dummy variables instead of purchased volume.

Table 3: The effects of ETF purchases on stock prices using dummy variables

\begin{tabular}{|c|c|c|c|c|c|c|}
\hline $\mathrm{C}$ & $\begin{array}{c}0.004 * * * \\
(15.920)\end{array}$ & $\begin{array}{c}0.001 * * * \\
(3.198)\end{array}$ & $\begin{array}{l}0.0004 \\
(1.337)\end{array}$ & $\begin{array}{c}0.0006^{*} \\
(1.765)\end{array}$ & $\begin{array}{l}0.0003 \\
(1.040)\end{array}$ & $\begin{array}{l}0.0003 \\
(0.916)\end{array}$ \\
\hline DUMMY & $\begin{array}{l}-0.014 * * * \\
(-25.489)\end{array}$ & & & & & \\
\hline DUMMY (-1) & & $\begin{array}{c}-0.001 * * * \\
(-2.775)\end{array}$ & & & & \\
\hline DUMMY (-2) & & & $\begin{array}{c}-8.57 \mathrm{E}-07 \\
(-0.803)\end{array}$ & & & \\
\hline DUMMY $(-3)$ & & & & $\begin{array}{c}-7.63 \mathrm{E}-05 \\
(-0.115)\end{array}$ & & \\
\hline DUMMY (-4) & & & & & $\begin{array}{l}0.0007 \\
(1.180)\end{array}$ & \\
\hline DUMMY (-5) & & & & & & $\begin{array}{l}0.0009 \\
(1.386)\end{array}$ \\
\hline Adj.R2 & 0.256 & 0.003 & -0.0001 & -0.0005 & 0.0002 & 0.0004 \\
\hline F-statistic & 649.737 & 7.703 & 0.644 & 0.013 & 1.393 & 1.921 \\
\hline Prob(F-statistic) & 0.000 & 0.005 & 0.422 & 0.908 & 0.238 & 0.165 \\
\hline $\begin{array}{l}\text { Akaike info } \\
\text { criterion }\end{array}$ & -6.113 & -5.820 & -5.816 & -5.816 & -5.816 & -5.816 \\
\hline D.W. & 2.117 & 2.080 & 2.017 & 2.014 & 2.016 & 2.017 \\
\hline
\end{tabular}

Notes) Parentheses are t-value. $* * *, * *$, and $*$ are significant at 1,5 , and $10 \%$ level.

The results are not so different from the ones of Table 1 . The analyses of Table 1 also fit well with the ones of Table 2. The purchases of ETF by the Bank could have been successfully conducted.

Moreover, regression analyses with the addition of the other variables listed before to the purchase of ETF are conducted. The estimated equations are in the equation (2).

Stock price $=\alpha+\beta_{1}$ ETF $+\beta_{2}$ exchange $+\beta_{3}$ 10bond $+\beta_{4}$ DOW

Table 4 presents the results of the regressions.

Table 4: Regression analyses: DOW

\begin{tabular}{|c|c|c|c|c|c|c|}
\hline $\mathrm{C}$ & $\begin{array}{c}0.003 * * * \\
(9.469)\end{array}$ & $\begin{array}{c}0.0009^{* * *} \\
(2.685)\end{array}$ & $\begin{array}{c}0.0006^{*} \\
(1.749)\end{array}$ & $\begin{array}{c}0.0003 \\
(1.040)\end{array}$ & $\begin{array}{c}0.0005 \\
(1.470)\end{array}$ & $\begin{array}{c}0.0003 \\
(0.879)\end{array}$ \\
\hline $\mathrm{ETF}$ & $\begin{array}{c}-1.32 \mathrm{E}-05^{* * *} \\
(-14.856)\end{array}$ & & & & & \\
\hline $\mathrm{ETF}(-1)$ & & $\begin{array}{c}-2.23 \mathrm{E}-06^{* *} \\
(-2.482)\end{array}$ & & & & \\
\hline
\end{tabular}




\begin{tabular}{|c|c|c|c|c|c|c|}
\hline ETF(-2) & & & $\begin{array}{c}-6.41 \mathrm{E}-07 \\
(-0.711)\end{array}$ & & \\
\hline ETF(-3) & & & $\begin{array}{c}5.69 \mathrm{E}-07 \\
(0.632)\end{array}$ & & \\
\hline ETF(-4) & & & & $\begin{array}{c}-1.60 \mathrm{E}-07 \\
(-0.178)\end{array}$ & \\
\hline ETF(-5) & & & & & $\begin{array}{c}8.56 \mathrm{E}-07 \\
(0.950)\end{array}$ \\
\hline Exchange & $1.014^{* * *}$ & $1.186^{* * *}$ & $1.185^{* * *}$ & $1.184 * * *$ & $1.184^{* * *}$ & $1.185^{* * *}$ \\
& $(25.036)$ & $(28.931)$ & $(28.853)$ & $(28.811)$ & $(28.814)$ & $(28.829)$ \\
\hline 10 bond & $-0.003^{* * *}$ & -0.0009 & -0.0005 & -0.0002 & -0.0004 & -0.0002 \\
& $(-3.999)$ & $(-1.125)$ & $(-0.671)$ & $(-0317)$ & $(-0.552)$ & $(-0.274)$ \\
\hline DOW & $0.141^{* * *}$ & $0.165 * * *$ & $0.167 * * *$ & $0.166^{* * *}$ & $0.166^{* * *}$ & $0.165^{* * *}$ \\
& $(6.840)$ & $(7.587)$ & $(7.688)$ & $(7.644)$ & $(7.650)$ & $(7.610)$ \\
\hline Adj.R2 & 0.396 & 0.328 & 0.328 & 0.326 & 0.326 & 0.326 \\
\hline F-statistic & 311.025 & 231.138 & 229.111 & 228.553 & 228.437 & 228.587 \\
\hline Prob(F-statistic) & 0.000 & 0.000 & 0.000 & 0.000 & 0.000 & 0.000 \\
\hline $\begin{array}{c}\text { Akaike info } \\
\text { criterion }\end{array}$ & -6.321 & -6.213 & -6.210 & -6.210 & -6.209 & 6.029 \\
\hline D.W. & 2.285 & 2.326 & 2.294 & 2.289 & 2.290 & 2.290 \\
\hline
\end{tabular}

Notes) Parentheses are t-value. ***,**, and * are significant at 1,5 , and $10 \%$ level.

These results are clear and confirmative. First of all, the analyses of Table 2 and Table 3 are again confirmed. Also, depreciation of the Japanese yen promotes a rise in stock prices. It seems natural as market participants think that depreciation promotes exports, so it causes a rise in stock prices, especially of global manufacturing companies in Japan. Moreover, the effects of US stock price movements have strong impacts on Japanese stock prices (See, Kurihara and Nezu, 2006). On the other hand, interest rates do not have impacts on Japanese stock prices. The low and almost zero interest rates seem to have no effect on the results.

Instead of DOW, S\&P is used for estimations. The estimated equation is in equation (3).

Stock price $=\alpha+\beta_{1}$ ETF $+\beta_{2}$ exchange $+\beta_{3}$ 10bond $+\beta_{4} S \& P$

The results are presented in Table 5 and are not so different from these of Table 4

Table 5: Regression analyses: S\&P

\begin{tabular}{|c|c|c|c|c|c|c|}
\hline $\mathrm{C}$ & $\begin{array}{c}0.003 * * * \\
(9.483)\end{array}$ & $\begin{array}{c}0.0009 * * * \\
(2.696)\end{array}$ & $\begin{array}{c}0.0006^{*} \\
(1.701)\end{array}$ & $\begin{array}{l}0.0003 \\
(1.021)\end{array}$ & $\begin{array}{l}0.0005 \\
(1.479)\end{array}$ & $\begin{array}{l}0.0003 \\
(0.856)\end{array}$ \\
\hline ETF & $\begin{array}{c}-1.33 \mathrm{E}-05^{* * * *} \\
(-14.911)\end{array}$ & & & & & \\
\hline ETF(-1) & & $\begin{array}{c}-2.28 \mathrm{E}-06^{* * *} \\
(-2.529)\end{array}$ & & & & \\
\hline $\operatorname{ETF}(-2)$ & & & $\begin{array}{c}-5.82 \mathrm{E}-07 \\
(-0.645)\end{array}$ & & & \\
\hline $\operatorname{ETF}(-3)$ & & & & $\begin{array}{c}5.80 \mathrm{E}-07 \\
(0.643)\end{array}$ & & \\
\hline ETF(-4) & & & & & $\begin{array}{c}-1.99 \mathrm{E}-07 \\
(-0.220)\end{array}$ & \\
\hline $\operatorname{ETF}(-5)$ & & & & & & $\begin{array}{c}8.75 \mathrm{E}-07 \\
(0.968) \\
\end{array}$ \\
\hline
\end{tabular}




\begin{tabular}{|c|c|c|c|c|c|c|}
\hline Exchange & $\begin{array}{c}1.014 * * * \\
(25.014)\end{array}$ & $\begin{array}{c}1.188^{* * *} \\
(28.923)\end{array}$ & $\begin{array}{c}1.186 * * * \\
(28.643)\end{array}$ & $\begin{array}{c}1.185^{* * *} \\
(28.801)\end{array}$ & $\begin{array}{c}1.186^{* * *} \\
(28.806)\end{array}$ & $\begin{array}{c}1.187 * * * \\
(28.821)\end{array}$ \\
\hline 10bond & $\begin{array}{c}-0.003 * * * \\
(-4.026)\end{array}$ & $\begin{array}{c}-0.001 \\
(-1.152)\end{array}$ & $\begin{array}{c}-0.0005 \\
(-0.672)\end{array}$ & $\begin{array}{c}-0.0002 \\
(-0.330)\end{array}$ & $\begin{array}{c}-0.0005 \\
(-0.579)\end{array}$ & $\begin{array}{c}-0.0002 \\
(-0.286)\end{array}$ \\
\hline S\&P & $\begin{array}{c}0.137 * * * \\
(6.431)\end{array}$ & $\begin{array}{c}0.160 \\
(7.129)\end{array}$ & $\begin{array}{c}0.162^{* * *} \\
(7.215)\end{array}$ & $\begin{array}{c}0.161^{* * *} \\
(7.177)\end{array}$ & $\begin{array}{c}0.161^{* * *} \\
(7.188)\end{array}$ & $\begin{array}{c}0.161^{* * *} \\
(7.188)\end{array}$ \\
\hline Adj.R2 & 0.395 & 0.326 & 0.324 & 0.323 & 0.323 & 0.323 \\
\hline F-statistic & 308.827 & 228.703 & 226.569 & 226.059 & 225.968 & 225.968 \\
\hline Prob(F-statistic) & 0.000 & 0.000 & 0.000 & 0.000 & 0.000 & 0.000 \\
\hline $\begin{array}{c}\text { Akaike info } \\
\text { criterion }\end{array}$ & -6.318 & -6.210 & -6.206 & -6.206 & -6.206 & -6.206 \\
\hline D.W. & 2.278 & 2.316 & 2.283 & 2.279 & 2.279 & 2.279 \\
\hline
\end{tabular}

Notes) Parentheses are t-value. $* * *, *$, and $*$ are significant at 1,5 , and $10 \%$ level.

Finally, Vector Auto-regression estimates are performed to check the movements of the shock of the ETF purchases. As confirmed in the previous analyses, the coefficients of the purchasing the same day and one-day before are negative, however, the coefficients change from negative to positive. The coefficients were not significant, however, checking these results seems to be extremely important.

The results of the regression are presented in Table 6 (DOW) and Table 7 (S\&P). Figure 1 and Figure 2 present the impulse response analysis results. Figure 1 is the DOW's case and Figure 2 is the S\&P's case respectively.

Table 6: Vector Auto-regression estimates: DOW

\begin{tabular}{|c|c|c|c|c|}
\hline & Stock price & ETF & exchange & DOW \\
\hline stockprice(-1) & $-0.105^{* * *}$ & $1920.702^{* * *}$ & $0.003 * *$ & $0.135^{* * *}$ \\
& $(-3.947)$ & $(3.241)$ & $(2.546)$ & $(5.406)$ \\
\hline ETF(-1) & $-2.26 \mathrm{E}-06^{* *}$ & $0.184 * * *$ & $5.95 \mathrm{E}-07$ & $-7.82 \mathrm{E}-07$ \\
& $(-2.129)$ & $(7.836)$ & $(1.122)$ & $(-0.787)$ \\
\hline Exchange(-1) & 0.008 & -1762.038 & $-0.088^{* * *}$ & $-0.185 * * *$ \\
& $(0.154)$ & $(-1.461)$ & $(-3.271)$ & $(-3.645)$ \\
\hline DOW(-1) & $0.501 * * *$ & $-8337.793^{* * *}$ & $0.107 * * *$ & $-0.226 * * *$ \\
& $(20.624)$ & $(-15.448)$ & $(8.871)$ & $(-9.931)$ \\
\hline C & $0.0007 * *$ & $134.305^{* * *}$ & $-5.33 \mathrm{E}-05$ & $0.0006^{* *}$ \\
& $(2.387)$ & $(18.535)$ & $(-0.326)$ & $(2.241)$ \\
\hline Adj.R2 & 0.185 & 0.142 & 0.050 & 0.057 \\
\hline F-statistic & 108.342 & 79.439 & 24.757 & 29.487 \\
\hline Akaike info & \multicolumn{5}{|c}{-6.159} \\
criterion & \multicolumn{5}{|c}{} \\
\hline
\end{tabular}

Notes) Parentheses are t-value. ***,**, and * are significant at 1,5 , and $10 \%$ level. 

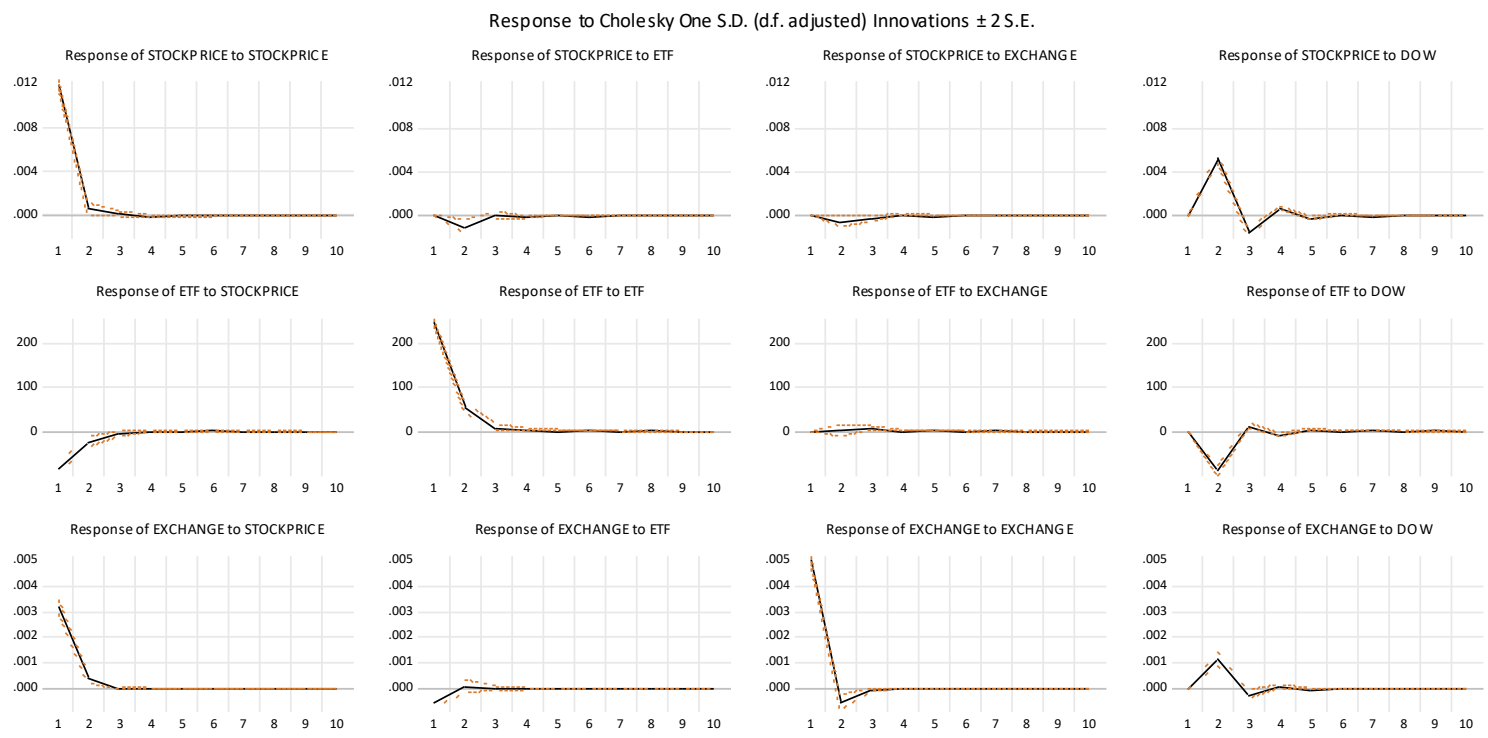

Response of DOW to STOCKPRICE
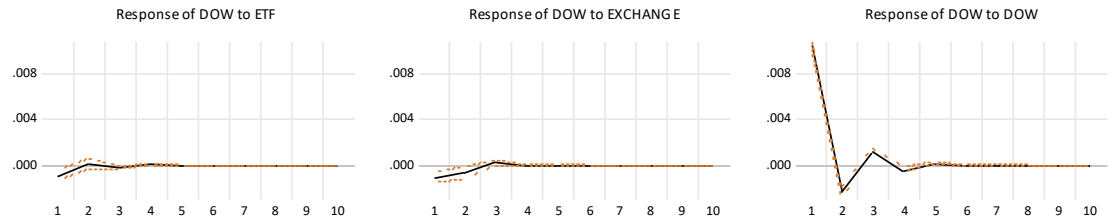

Figure 1: Impulse responses: DOW

Table 7:Vector Auto-regression estimates: S\&P

\begin{tabular}{|c|c|c|c|c|}
\hline & Stock price & ETF & exchange & S\&P \\
\hline Stock price(-1) & $-0.102^{* * *}$ & $1868.714 * * *$ & $0.035^{* *}$ & $0.118^{* * *}$ \\
& $(-3.859)$ & $(3.109)$ & $(2.631)$ & $(4.885)$ \\
\hline ETF(-1) & $-2.28 \mathrm{E}-06^{* *}$ & $0.185^{* * *}$ & $5.87 \mathrm{E}-07$ & $-6.96 \mathrm{E}-07$ \\
& $(-2.164)$ & $(7.866)$ & $(1.108)$ & $(-0.722)$ \\
\hline exchange(-1) & 0.005 & -1688.514 & $-0.089 * * *$ & $-0.163 * * *$ \\
& $(0.098)$ & $(-1.401)$ & $(-3.308)$ & $(-3.307)$ \\
\hline S\&P(-1) & $0.530^{* * *}$ & $-8628.858^{* * *}$ & $0.111^{* * *}$ & $-0.227 * * *$ \\
& $(21.318)$ & $(-15.536)$ & $(8.908)$ & $(-9.988)$ \\
\hline C & $0.0007 * *$ & $134.896^{* * *}$ & $-6.09 \mathrm{E}-05$ & $0.0007 * *$ \\
& $(2.269)$ & $(18.624)$ & $(-0.373)$ & $(2.525)$ \\
\hline Adj.R2 & 0.195 & 0.143 & 0.048 & 0.055 \\
\hline F-statistic & 115.646 & 80.146 & 24.924 & 28.757 \\
\hline Akaike info & \multicolumn{5}{|c}{-6.227} \\
criterion & &
\end{tabular}

Notes) Parentheses are t-value. ***, **, and * are significant at 1,5 , and $10 \%$ level. 

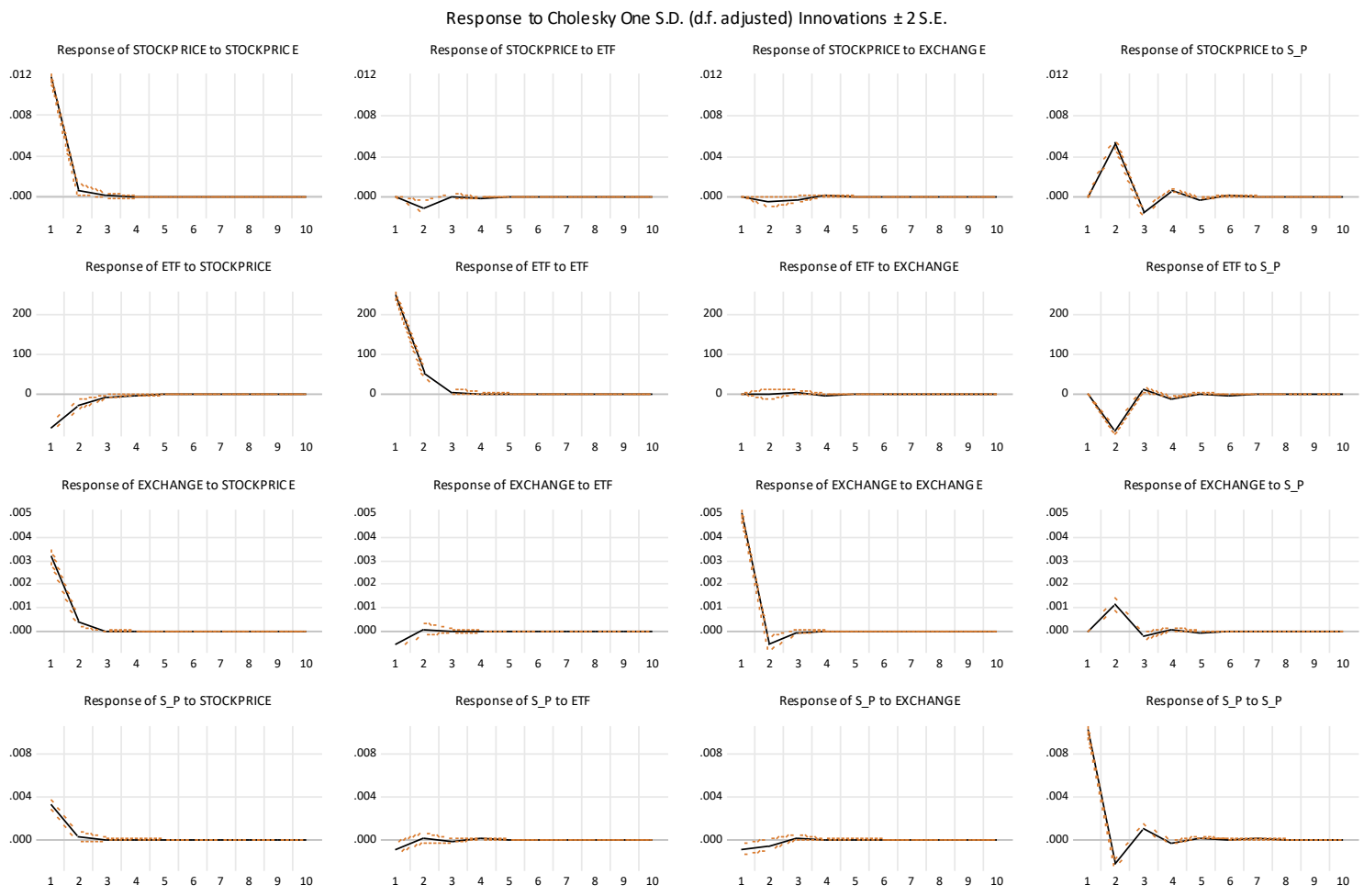

Figure 2: Impulse responses: S\&P

The results of Table 4 and Table 5 were confirmed again. Figure 1 and Figure 2 show that the effects of ETF purchases by the BOJ on stock prices appears a few days after the BOJ's purchases and the shock disappears quickly. The purchases do not cause turmoil the markets. On the other hands it should be noted that stock prices decline at first.

\section{Conclusions}

The Japanese central bank, the Bank of Japan (BOJ) has introduced a drastic quantitative easing policy to combat deflation from the 2010s. Under this policy, the BOJ has purchased exchange-traded funds (ETF) as well as huge amounts of domestic governments bonds. Along with quantitative easing, qualitative easing has been conducted in Japan. This paper investigates the effect of ETF purchases by the Bank on Japanese stock prices. Empirical results show that the purchases have been successfully conducted to prevent decreasing stock prices, however, whether the purchases directly promoted stock price rising or not is uncertain in the short-run. On the other hand, as stock prices have been increasing since then, the purchases created situations such as preventing a decrease to stock prices and promoting the prices in the long-run. At first glance, the policy appears to have been a failure, but it can be judged successful in that it avoided market turmoil.

Finally, when and how the sales of the ETF should be examined. If the purchases of the ETF can be judged successfully without turmoil or distortion of markets, the purchases are massive. Moreover, not only examining the effects of purchases of ETF but also the 'exit' of the purchases should be examined. There is further room for study.

\section{Acknowledgements}

We appreciate reviewers' valuable comments and suggestions. 


\section{References}

Ben-David, I., Franzoni, F., and Moussaw, R. (2018) Do ETFs increase volatility? Journal of Finance, 73(6), 2471-2535.

Charoenwong, B, Morck, R., and Wiwattanakantang, Y. (2019) Asset prices and corporate responses to Bank of Japan ETF purchases. NBER Working Paper, 25525.

Cheng, S., Massa, M., and Zhang, H. (2019) The unexpected activeness of passive investors: A worldwide analysis of ETFs. Review of Asset Pricing Studies, 9(2), 296-355.

Chang, C.-L., Hsieh, T.-L., and McAleer, M. (2018) Connecting VIX and stock index ETF with VAR and Diagonal BEKK. Journal of Risk and Financial Management, 11(4), 1-25.

Fassas, A. P. and Papadamou, S. (2018) Variance risk premium and equity returns. Research in International Business and Finance, 46, 462-470. https://doi.org/10.1016/j.ribaf.2018.06.003

Hattori, T. (2020) The impact of quantitative and qualitative easing on term structure: Evidence from micro-data. Economics Letters, 195. 109347.

Kurihara, Y. and Nezu, E. (2006) Recent stock price relationships between Japanese and US stock markets. Studies in Economics and Finance, 23(3), 211-226. https://doi.org/10.1108/10867370610711057/

Kurihara, Y. (2014) Has interest rate policy of the Bank of Japan influenced financial markets? Journal of Finance and Economics, 2(2), 77-85.

Kurihara, Y. (2016) Effectiveness of the zero interest rate policy for financial markets in Japan: principal components analysis. Applied Economics and Finance, 3(3), 103-111. https://doi.org/10.11114/aef.v3i3.1532

Lam, K-C. (2015) Did Abenomics' two arrows hit the bulls? Journal of Applied Finance and Banking, $5(3), 47-61$.

Lee, K., and Kim, S.-H. (2018) Do leveraged/inverse ETFs wag the underlying market? Evidence from the Korean stock market. Hitotsubashi Journal of Economics, 5982, 83-94.

Li, M., and Zhao, X. (2014) Impact of leveraged ETF trading on the market quality of component stocks. North American Journal of Economics and Finance, 28, 90-108. http://dx.doi.org/10.1016/j.najef.2014.02.001

Fukuda, S. (2011) Market-specific and currency-specific risk during the global financial crisis: Evidence from the interbank markets in Tokyo and London. Journal of Banking \& Finance, 36(12), 3185-3196. http://dx.doi.org/10.1016/j.jbankfin.2012.01.003

Fujiwara, I., Nakazono, Y., and Ueda, Y. (2015) Policy regime change against chronic deflation? Policy option under a long-term liquidity trap. Journal of the Japanese and International Economies, 37, 59-81. http://dx.doi.org/10.1016/j.jjie.2015.05.005

Kyriazis. N.A., Koulis, A., Papadamou S, and Beneki, C. (2020) Selectivity and market timing skills in emerging Greek equity mutual funds during the sovereign debt crisis. Studies in Business and Economics, 15(2), 133-150.

Liu, Q., and Tse, Y. (2017) Overnight returns of stock indexes: Evidence from ETFs and futures. International Review of Economics and Finance, 48, 440-451.

Matousek, R., Papadamou, S. T., Šević, A., and Tzeremes, N. G. (2019) The effectiveness of quantitative easing: Evidence from Japan. Journal of International Money and Finance, 99, 102068. https://doi.org/10.1016/j.jimonfin.2019.102068

Narend, S., and Thenmozhi, M. (2019) Do country ETFs influence foreign stock market index? Evidence from India ETFs. Journal of Emerging Market Finance, 18, 59S-86.

Nie, H. Jiang, Y. and Yang, B. (2018) Do different time horizons in the volatility of the US stock market significantly affect the China ETF market? Applied Economics Letters, 25(11), 747-751. http://dx.doi.org/10.1080/13504851.2017.1363863

Papadamou, S., Kyriazis, N. A., \& Mermigka, L. (2017). Japanese mutual funds before and after the crisis outburst: A style-and performance-analysis. International Journal of Financial Studies, 5(1), 9. https://doi.org/10.3390/ijfs5010009 
Romotis, G. G. (2017) Testing price integration between US and emerging ETF markets from a 'law of one price' perspective. International Journal of Accounting and Finance, 7(4), 271-300.

Rompotis, G. G. (2018) Spillover effects between US ETFs and emerging stock markets. Global Business and Economics Review, 20(3), 327-372.

Sanderson, R. and Lumpkin-Sowers, N. I. (2018) Buy and hold in the new age of stock market volatility: A story about ETFs, International Journal of Financial Studies, 6(3), 1-14.

Tse, Y. (2012) The relationship among agricultural futures, ETFs, and the U.S. stock market. Review of Futures Markets, 20(2), 141-159.

Wang, J., Kang, H., Xia, F., and Li, G. (2018) Examining the equilibrium relationship between the Shanghai 50 stock index futures and the Shanghai 50 ETF options markets. Emerging Markets Finance and Trade, 54(11), 2557-2575. http://dx.doi.org/10.1080/1540496X.2018.1483824

Yamori, N. (2011) Commodity ETFs in the Japanese stock exchanges. Journal of Advanced Studies in Finance, 2(1), 47-52. 